\title{
A 'Fine Specimen of Neronian Brickwork' in Victorian London: How the STRAND Lane Cold Bath Became Roman
}

\author{
Michael Trapp ${ }^{1}$
}

Published online: 12 December 2016

(C) The Author(s) 2016. This article is published with open access at Springerlink.com

\begin{abstract}
This paper addresses the myth of the Strand Lane cold bath's Roman origins: it explains how this dream of Rome first emerged in the 1830s and became consolidated in the $1840 \mathrm{~s}$, and documents the means by which it was propagated, and the extent to which it was debated, between then and the 1890s. It is suggested that the origins of the idea were heavily indebted to popular awareness of the baths of Pompeii, spread both by archaeological publication and by Bulwer-Lytton's Last Days and its offshoots; that the consolidation was the work of Charles Knight and Charles Dickens; and that the vigorous survival of the mirage for the remainder of the century was down in part to the absence of any other large-scale standing Roman structure in the capital, and in part to the lack of any plausible alternative story of the bath's real origins. The auxiliary myth of the 'Essex' bath is also discussed, and the whole argument illuminates not only the history of the monument itself, but also Victorian engagement with the Roman past and the historical fabric of London more generally.
\end{abstract}

\section{Introduction}

The brick tank on London's Strand Lane, now managed by Westminster City Council on behalf of the National Trust under the name of the Strand Lane 'Roman' Bath (Fig. 1), never was Roman and only came into use as a cold bath in the 1770s. It began life as part of a cistern for a fountain in the gardens of the old Somerset House, as modernized and expanded by James I for his queen, Ann of Denmark, in

Michael Trapp

michael.trapp@kcl.ac.uk

1 Department of Classics, King's College London, Strand, London WC2R 2LS, UK 
Fig. 1 The Bath today (photo: author)

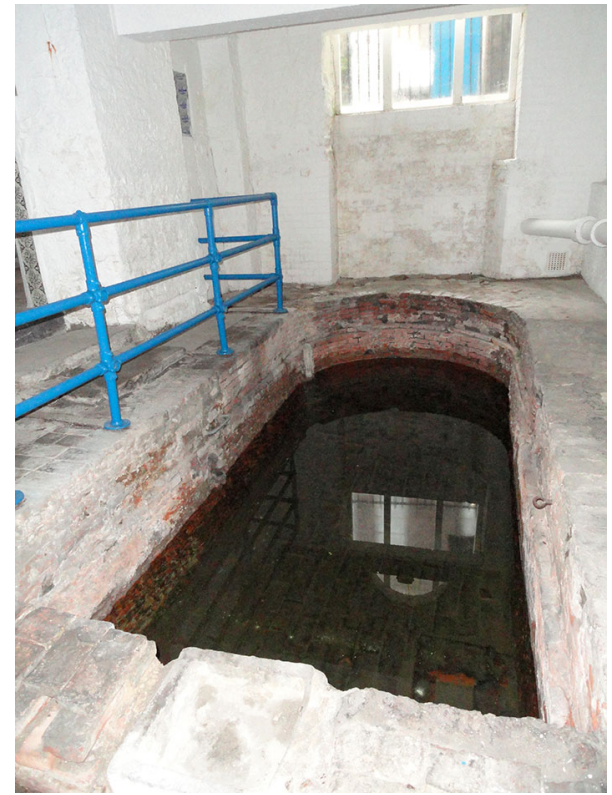

1609-1612. ${ }^{1}$ In 1776, it was refurbished for use as a plunge-bath, open to a paying public, and two years later was joined by a second, purpose-built basin close beside it. $^{2}$ By the later decades of the nineteenth century, however, it was widely believed to be a rare and precious survival of a much earlier period, a genuine Roman bath still in use in its original function after nearly two thousand years. Walter Pater, for instance, is claimed to have referred to it as 'Rome in London' (as balanced by the 'Athens in London' represented by the Greek cemetery in Norwood), and to have 'descended the steps and approached the cool clear water' in the company of the Rector of St Mary-le-Strand, discoursing on 'the different Romans who had distinguished themselves in our island'. ${ }^{3}$ It is the aim of this paper to explain how this change of identity came about in the first place, and why, once suggested, it proved so attractive and so durable. The story that emerges turns out to illuminate not only the perceived history of the Bath, but also Victorian engagement with the classical past and the historical topography of London more generally.

\footnotetext{
${ }^{1}$ M. Trapp, 'The Denmark House Helicon: Iconography and Surviving Traces', Studies in the History of Gardens and Designed Landscapes, 32, 2012, pp. 241-57; Id., 'New Light on the Strand Lane Bath', National Trust Historic Houses \& Collections Annual, 2012, pp. 44-7.

2 M. Trapp, 'The Georgian History of the Strand Lane Roman Bath', The London Journal, 39, 2014, pp. 142-67.

3 T. Wright, The Life of Walter Pater, II, Everett, 1908, pp. 187-8. Some caution is in order here, however. Wright's source for this snippet of information was the unreliable Richard C. Jackson, who seems to have propagated a highly self-serving account of the aesthete's later life; see e.g., S. Bann (ed.), The Reception of Walter Pater in Europe, London, 2004, p. 10.
} 


\section{The Origins of Romanness}

Knowledge of the Bath's true origins was lost some time in the middle of the eighteenth century. ${ }^{4}$ It did not take long for creative fictions to emerge to replace it. Already in the 1770s, Mr James Smith of 33 Surrey-street - the man who seems to have refurbished the derelict old fountain cistern and brought it back into use as a public cold bath - was proclaiming in his advertisements in the papers that his newly opened facility was 'lately the property of Sir Philip Meadows'. 5 The longlived and distinguished Sir Philip $(1662-1757)^{6}$ had indeed lived in Surrey Street, next to the Bath, in the 1740s, when he was Comptroller of Army Accounts and occupying the Government-rented mansion house that previously stood (until 1765) on the site of Nos 33-35. But there is no strong reason to suppose that he knew that there was anything more than a water-tank in his backyard, let alone used it as a bath, and he was only ever an occupant of the property, not its owner. ${ }^{7}$ Smith's words are evidently an attempt to recommend his new venture by a noble connection rather than a record of fact; they are a publicist's ploy.

The same seems in fact to be true of the story of Roman origins. At least, the earliest place it has yet come to light is in a trade directory from the year 1838, which contains as its sole entry for Strand Lane 'Scott Chas. Roman Spring Bths (sic) '. ${ }^{8}$ When he died in 1868 , Charles Scott's obituary notice commemorated him as 'for twenty-eight years proprietor of the old Roman Bath, Strand Lane'. ' Since other records suggest that this twenty-eight-year period came to an end with the transfer of the ownership of No 33 Surrey Street to one Henry Cutler and the lease of the bath to John Howell in 1864/1865, that fixes the beginning of Scott's occupancy to $1836 / 1837$, a year or so before the entry in the directory. ${ }^{10}$ It would make very good sense if a new proprietor, taking over what may by then not have

\footnotetext{
4 The true origins were known to Thomas Vernon, who owned the house subsequently occupied by Sir Philip Meadows from 1710 to 1726, and to the compilers of a survey made in 1724 of the Somerset House perimeter: see Trapp, 'Denmark House Helicon', p. 242; 'New Light', p. 47 (n. 1 above).

5 Gazetteer and New Daily Chronicle for 20 May 1778, Morning Chronicle 22 May 1778; cf. Morning Post and Daily Advertiser, 7 July 1780: see Trapp, 'Georgian History' (n. 2 above), pp. 150-54.

6 On Sir Philip, see Trapp, 'Georgian History' (n. 2 above), p. 154.

7 The owner, who rented it to the Government for Sir Philip's use, was Sir Joseph Danvers: see Trapp, 'Georgian History' (n. 2 above), pp. 147, 154.

8 Robson's London Directory and Street Key ... for 1838, London, 1838, p. 314.

9 See J. Diprose, Some Account, I, London, 1868, p. 267.

${ }^{10}$ Cutler advertises himself as the proprietor of the Bath in a number of newspapers and periodicals including the Lancet - on 29 July of that year and property deeds in the King's College Archives (Box KA/T/21) show him coming into possession of No. 33 Surrey Street, through his wife Mary Ann (née Tims), at about the same time. The property status of the Bath needs a word of explanation. Although it belonged with the freehold of No. 33 Surrey Street, it was separately leased from some time early in the 19 th century onwards (in 1850, for example, the annual rent for the house was $£ 75$ and for the Bath $£ 10-$ advertisement in the Times of 15 May, p. 11). The property deeds in the KCL Archive (KCL KA/T/21/5/ 5/6) show that Scott only took over the lease of the Bath in 1843, from one John William James Dawson, even though the 1838 directory and the 1841 census show that he was running it and living over it already by those dates. Scott appears, along with his wife Jane and his daughters Elizabeth and Maria, in the 1841 and 1851 censuses, and with the daughters alone in 1861, by which time he is 71 and they are 43 and 33 , respectively.
} 
been a particularly flourishing concern - the fashion for cold bathing which had continued unabated through the whole of the eighteenth century ${ }^{11}$ had waned with the early years of the nineteenth - had looked for colourful ways of drumming up new custom.

At all events, no suggestion of a Roman origin for the Bath earlier than 1838 has yet been found, and conversely, direct references to the Bath without this qualification manifestly occur up to only a few years previously. In 1802, when a witness at a trial at the Old Bailey - James Talboys, son of the Beadle of St Clement Danes, resident at the Watch House in Strand Lane - had to identify himself, he did so as the attendant of 'the cold-bath in Strand-lane'. ${ }^{12}$ In 1815 it was being advertised, after the name of its founder, as 'Smith's Cold Bath, Strand-lane'. ${ }^{13}$ When the lease was advertised in 1827, it was for, simply, 'the long-established and celebrated COLD BATH in Strand-lane'. ${ }^{14}$ And a plan of No. 32 Surrey Street preserved in the Norfolk estate papers, which probably dates to 1830 , marks it just as a 'bath house'. 15

What exactly gave Scott his bright idea can of course only be guessed at. The bath's physical appearance - the rounded end, the broad, thin red bricks it is built from, and the round-headed brick and stone vault enclosing it - must have been a major factor (Figs 1,2). As we shall see these are certainly the features that are again and again referred to as corroborating evidence once the Roman idea becomes established. But the full context for Scott's ploy can plausibly be argued to have been created by a number of further factors: an awareness of recent finds of Roman material elsewhere in London, a growing public interest in and knowledge of Roman bathing, stimulated by both archaeological discoveries and by fashionable historical fiction, and (as the enabling condition of both of these first two factors) the great increase in the availability of periodicals and cheap books that began to gather pace in Britain in the 1830 s. $^{16}$

Roman Britain was a well-established topic of antiquarian study already by the end of the eighteenth century. ${ }^{17}$ Much more attention had however been paid to the

\footnotetext{
11 See Trapp, 'Georgian History' (n. 2 above), pp. 159-63.

12 Old Bailey Proceedings, Sir J. Eamer, Mayor, Fifth Session, 1802, no. 469 ([printed edn.] p. 322; online at http://www.oldbaileyonline.org/browse.jsp?id=t18020602-51\&div=t18020602-51\&terms= Talboys\#highlight).

13 The Times 28 June 1815, p. 1.

14 The Times 18 October 1827, p. 1.

15 No. 32 Surrey Street, because although the older of the two baths stands behind No. 33 and both of them belonged to that property, the newer of them lay behind No. 32. The northern boundary of the Arundel (Duke of Norfolk's) Estate passed east-west along the party-wall between 32 and 33 but then broke south so as to exclude the back-house containing the newer basin (and the building above it, No. 5 Strand Lane), before resuming its east-west course across Strand Lane to the boundary wall of Somerset House.

${ }^{16}$ For this last factor, cf. V. Hoselitz, Imagining Roman Britain: Victorian Responses to a Roman Past, Woodbridge and Rochester, 2007, p. 78; the steam printing press had been patented in 1810 and was first put to use for newspaper production in England in 1814.

17 R. Sweet, Antiquaries: The Discovery of the Past in Eighteenth-Century Britain, London and New York, 2004, Ch. 5, pp. 155-87, with the summary at 186: 'By the early 19th century, the study of Roman antiquities had been consolidated.'
} 


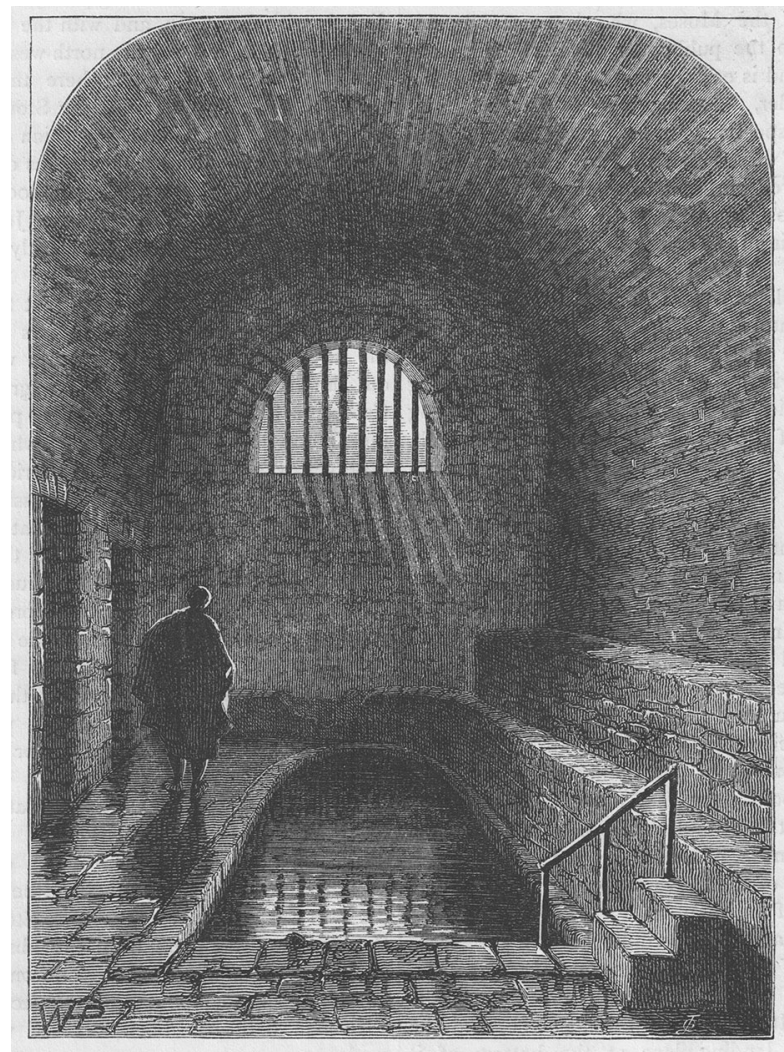

OLD ROMAN BATH, STRAND LANE.

Fig. 2 The Bath in Victorian vision: W. Thornbury and E. Walford, Old and New London, III, 1878, p. 78 (photo: author)

more obvious remains elsewhere in the country (Hadrian's Wall, the Antonine Wall, and the Old Work at Wroxeter, to name only a few) than to the metropolis. The most comprehensive and authoritative work of the century, John Horsley's Britannia Romana of 1732, written from Morpeth in Northumberland, began its survey of monuments with the two northern Walls and worked its way southwards with dwindling enthusiasm; Middlesex, Essex and Hamshire [sic] merited only one page of illustrations between them. ${ }^{18}$ In London, the first really widely publicized discovery of the remains of Roman building in the capital may only have come in 1848, with the unearthing of the Billingsgate house and baths on Lower Thames Street, uncovered in the course of work for the new Coal Exchange, ${ }^{19}$ but smaller finds, of both buildings and artefacts, had been made in considerable quantity

\footnotetext{
18 J. Horsley, Britannia Romana: or the Roman Antiquities of Britain: in Three Books, London, 1732.

19 See the coverage, with four woodcut illustrations, in the Illustrated London News for 5 February 1848, p. 78 ('Roman villa discovered in Lower Thames-street').
} 
through the 1830s, and discussed intensively enough in specialist journals for news of them to leak out into the more general press as well. By way of example, one can point to the exchange between two FSAs, Alfred John Kempe (1785-1846) and Charles Roach Smith (1807-1890), who were among the most generally respected experts on the antiquities of Roman London in this period. ${ }^{20}$ In 1832 , Kempe published 'An Account of various Roman antiquities discovered on the site of the Church of St. Michael, Crooked Lane, and in Eastcheap' in the journal Archaeologia. ${ }^{21}$ Smith followed this up with 'Observations on the Roman Remains found in various parts of London, in the years 1834, 1835, 1836 ... Communicated in a letter to A. J. Kempe, Esq. F.S.A.', published in the same periodical five years later, ${ }^{22}$ and this was in its turn noted and summarized in the Gentleman's Magazine for January-June 1838. ${ }^{23}$ The Gentleman's Magazine, moreover, can be seen regularly reporting Roman finds, in London and around the country, in its 'Antiquarian Researches' column between 1835 and 1838. It cannot be guaranteed that Charles Scott was a reader of either the Gentleman's Magazine or Archaeologia, but talk about the Roman remains of London was clearly in the air in the mid-1830s, and may well have inspired him to extend their reach westward with this new 'discovery' of his own.

But Roman remains, and specifically Roman baths, were in the air for other reasons too in the 1830s. 1834 had seen the publication of Edward Bulwer-Lytton's novel The Last Days of Pompeii. It was an instant popular success, going into a second edition within five months of publication (this in spite of the first having been printed in numbers 'perhaps unprecedented except in the novels of Sir Walter $\mathrm{Scott}^{24}$ ), and adapted for the London stage even sooner. ${ }^{25}$ Baths and bathing bulk large in the opening phase of the novel: one of the participants in the opening exchange (Clodius, the young man marked by the cut of his tunic as 'a gentleman and a coxcomb') announces he is on his way to the baths, and his arrival there in Ch. 6 , where he meets up with Glaucus, Sallust and Pansa, is the pretext for an elaborate

\footnotetext{
${ }^{20}$ On Kempe and Roach Smith, see their respective DNB entries, along with: Hoselitz, Imagining Roman Britain (n. 16 above), p. 20 and passim; V. Zimmerman, Excavating Victorians, Albany, 2008, Ch. 4; and S. Scott, 'Pioneers, Publishers and the Dissemination of Archaeological Knowledge: A Study of Publishing in British Archaeology 1816-1851', Internet Archaeology, 35, §4.2.

21 Archaeologia, 24, 1832, pp. 190-208.

22 Archaeologia, 27, 1837, pp. 140-52.

23 Gentleman's Magazine, 163, 1838, p. 56.

24 E. Bulwer-Lytton, 'Advertisement to the Second Edition', March 1835. For the immediate reception of the novel, see W. St Clair and A. Bautz, 'Imperial Decadence: The Making of Myths in Edward BulwerLytton's The Last Days of Pompeii', Victorian Literature and Culture, 40, 2012, pp. 359-96 at 368-75.

25 J. D. Buckstone, The Last Days of Pompeii; or, Seventeen Hundred Years Ago, which played for over two months at the Adelphi Theatre on the Strand, less than half a mile from Strand Lane, starting on 15 December 1834; E. Fitzball, The Last Days of Pompeii; or, The Blind Girl of Tessaly, which ran at the Victoria Theatre in the Waterloo Road from 27 December; and J. Farrell, The Last Days of Pompeii, or the city of the dead!, which ran at the Pavilion Theatre in Whitechapel from 19 January 1835. See N. Daly, The Demographic Imagination and the Nineteenth-Century City: Paris, London, New York, Cambridge, 2015, pp. 36-41 and nn. 53-5 on 202; St Clair and Bautz, 'Imperial Decadence' (n. 24 above), pp. 359-96 at 371-5 and 393. For the influence of Last Days in initiating a long-lasting fashion for historical fiction about the Roman world ('toga novels'), see S. Goldhill, Victorian Culture and Classical Antiquity, Princeton, 2011, pp. 153-63, 193-244, Chs 5-6.
} 
and archaeologically scrupulous description of their physical layout and the ritual of Roman bathing which takes up just about the whole of the chapter. ${ }^{26}$ The prominence of this description, so close the start of the novel, and providing one of its first narrative focuses, must have been in many minds in London in the mid1830s.

Nor was Last Days the only available point of reference. Bulwer-Lytton was himself avowedly dependent for his archaeological and topographical descriptions of Pompeii on Sir William Gell's illustrated survey Pompeiana. First published in 1817-1819, this pioneering exercise in bringing an archaeological excavation to a broader public had gone into a two-volume second edition in 1832. Among the additions which marked this expanded edition out from its predecessor was its description of the Pompeii Forum Baths, which had been discovered and excavated by Antonio Bonucci in 1824 (Fig. 3). ${ }^{27}$ The chapters containing this description were illustrated by a dozen or so engravings, no fewer than five of which emphasize the prevalence of vaulted ceilings and low levels of natural light. ${ }^{28}$ English readers had not, however, had to wait for Gell's second edition for knowledge of the Forum Baths and their appearance. They had already featured, with two engraved illustrations of vaulted ceilings, in William Clarke's Pompeii, the first volume of which appeared in a year earlier, in 1831: page 159 offered a 'View of the Tepidarium' (Fig. 4) and page 186 a 'Representation of baths, from the paintings discovered in the Baths of Titus', showing a whole series of interconnected, but individually modestly sized vaulted chambers. ${ }^{29}$ Appearing as it did as an accessibly priced volume in The Library of Entertaining Knowledge (an offshoot of the Society for the Diffusion of Useful Knowledge's Library of Useful Knowledge), Clarke's work, derivative though it was, will have circulated far more widely among a middle and (perhaps) working class readership than Gell's, and is probably a more likely source for Charles Scott than either Gell or the Gentleman's Magazine. At all events, it is clear that this body of recently published material - Lytton as well as Gell and Clarke - had created the conditions for considerable public interest in Roman baths and Roman bathing by the mid-1830s. Scott would have had every reason to think that announcing the presence of a previously unnoticed bath in central London would fall on enthusiastically receptive ears, and every reason to suppose that its physical appearance would make the announcement a plausible one.

\footnotetext{
${ }^{26}$ The chapter is entitled 'The gay life of the Pompeian lounger. A miniature likeness of the Roman baths' and it ends with the words 'Passing now once again into the cooler air, and so into the street, our gallants of that day concluded the ceremony of a Pompeian bath.' In the description of the physical layout, emphasis is placed on the vaulted ceilings and the preference for blocking off natural light, both details which resonate with the Strand Lane Bath, particularly in its mid-19th century configuration.

27 W. Gell, Pompeiana: The Topography, Edifices, and Ornaments of Pompeii, the Results of Excavations Since 1819, London, 1832. Chapter 6 (pp. 83-130) is on 'Thermae excavated in 1824' and Ch. 7 (pp. 131-41) on 'Women's Baths'.

28 XXVII (Frigidarium); XXVIII (Natatio); XXIX (Tepidarium); XXXI (Calidarium); XXXIII (Frigidarium and Piscina of Women's Baths); of these the last is of special interest in connection with the Strand Lane Bath, since it shows both a plain vaulted ceiling and (albeit distantly, in one corner) a cold plunge bath.

29 W. Clarke, Pompeii, I, London, 1831. As will emerge shortly, the publisher of this volume, Charles Knight, had a still closer connection to the Strand Lane bath and its putative Romanness.
} 
Fig. 3 The Frigidarium and

Piscina of the Women's Baths at

Pompeii, from W. Gell,

Pompeiana, new edition, 1832, pl. XXXIII (photo: Heidelberg

University Library)

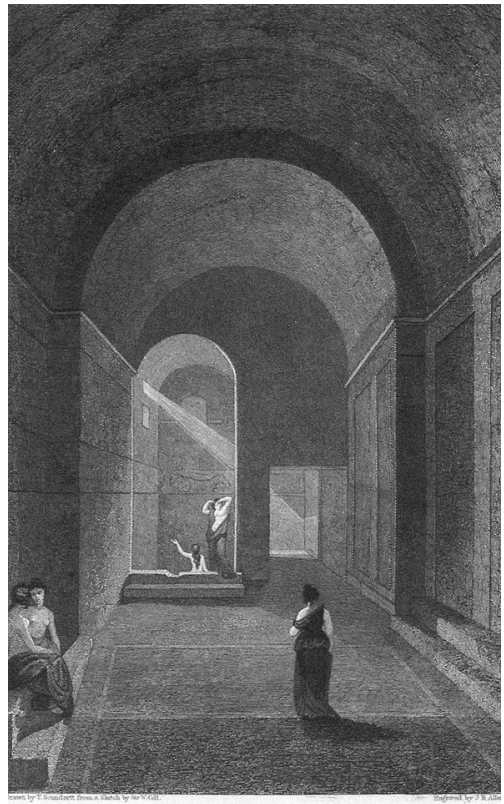

2 (1) M I I T

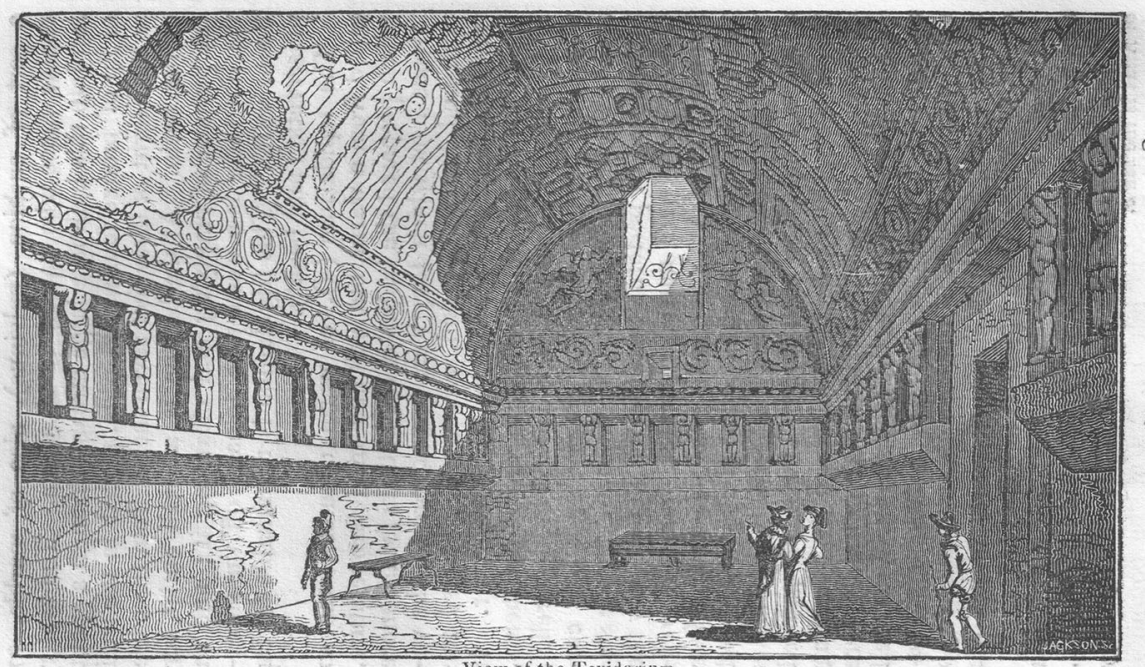

View of the Tepidarium.

Fig. 4 The Tepidarium of the Forum Baths at Pompeii, from W. Clarke, Pompeii, I, 1831, p. 159 (photo: author) 


\section{Canonization and the Beginnings of an Antiquarian Tradition}

What immediate effect Scott's invention actually had on customer footfall is unknown. As an antiquarian claim, however, it succeeded better than he can possibly have imagined, since it is essentially thanks to him that the Strand Lane 'Roman' Bath is still standardly referred to in this way, however carefully hedged about with inverted commas, and thanks to him that Westminster Council's information board outside the Bath still feels it has to allow its readers permission to believe it to be Roman if they wish to. But the story did not achieve this long-lasting hold on the public imagination unaided. It took two further interventions in the succeeding decade and a half to give it its full purchase and ensure its durability.

The first of these interventions was the publication of Volume II of the historical guidebook London, edited by the indefatigable journalist and champion of popular education, Charles Knight, in 1841. Published in 150 weekly parts, subsequently gathered into six volumes, between March 1841 and February 1844, London was a ground-breaking work of higher popularization, covering the history, monuments, customs and institutions of the capital for the general reader in unprecedented detail. Like most of Knight's publications, ${ }^{30}$ it had the didactic aim of bringing wholesome knowledge to a readership keen on self-improvement through the written word. It was also copiously illustrated, in line with Knight's lively appreciation of the power of images to enliven his texts and attract his target readership. Chapter 36, composed by Knight's frequent contributor John Saunders (1810-1895), was the second of two dealing with the Strand and its monuments. ${ }^{31}$ It was headed by an engraving of the Bath by the artist John Wykeham Archer (1808-1864) and was cast as an account of a visit the two men had paid there in the preceding year (Fig. 5). ${ }^{32}$

In a trope which was to have a long and vigorous afterlife in the history of writing about the Bath, ${ }^{33}$ Saunders presents himself and his companion as having stumbled upon it by accident, with no previous suspicion of its very existence, and with initial incredulity about its alleged antiquity:

Among those curious narrow lanes which extend from the Strand downwards to the Thames, there is one called Strand Lane ... It is a place which few persons besides the inhabitants are at all familiar with ... We were roaming carelessly through these lanes, thinking there could be little or nothing in them to repay the curious visitor, when that announcement [sc. on the notice outside No. 5 Strand Lane] attracted our attention, and we read 'The Old Roman Spring Bath!' With some surprise and a great deal of incredulity we desired to

\footnotetext{
30 See V. Gray, Charles Knight: Educator, Publisher, Writer, Aldershot, 2006. Knight in London was aiming at a somewhat higher social level than his publications for the SDUK, the Library of Entertaining Knowledge and Penny Cyclopaedia, which were intended for a more working-class diffusion (even though they may not always have achieved it).

31 C. Knight (ed.), London, II, London, 1842, pp. 165-80.

32 The engraving was taken from a watercolour sketch of the Bath Archer had presumably done at the time, now in the British Museum (Prints \& Drawings, 1874,0314.219), having gone there with a large collection of antiquarian illustrations amassed by William Twopeny (1797-1873), for whom Archer also worked.

33 Indeed, as Dan Orrells points out to me, a well-worn trope in Victorian travel writing more generally.
} 


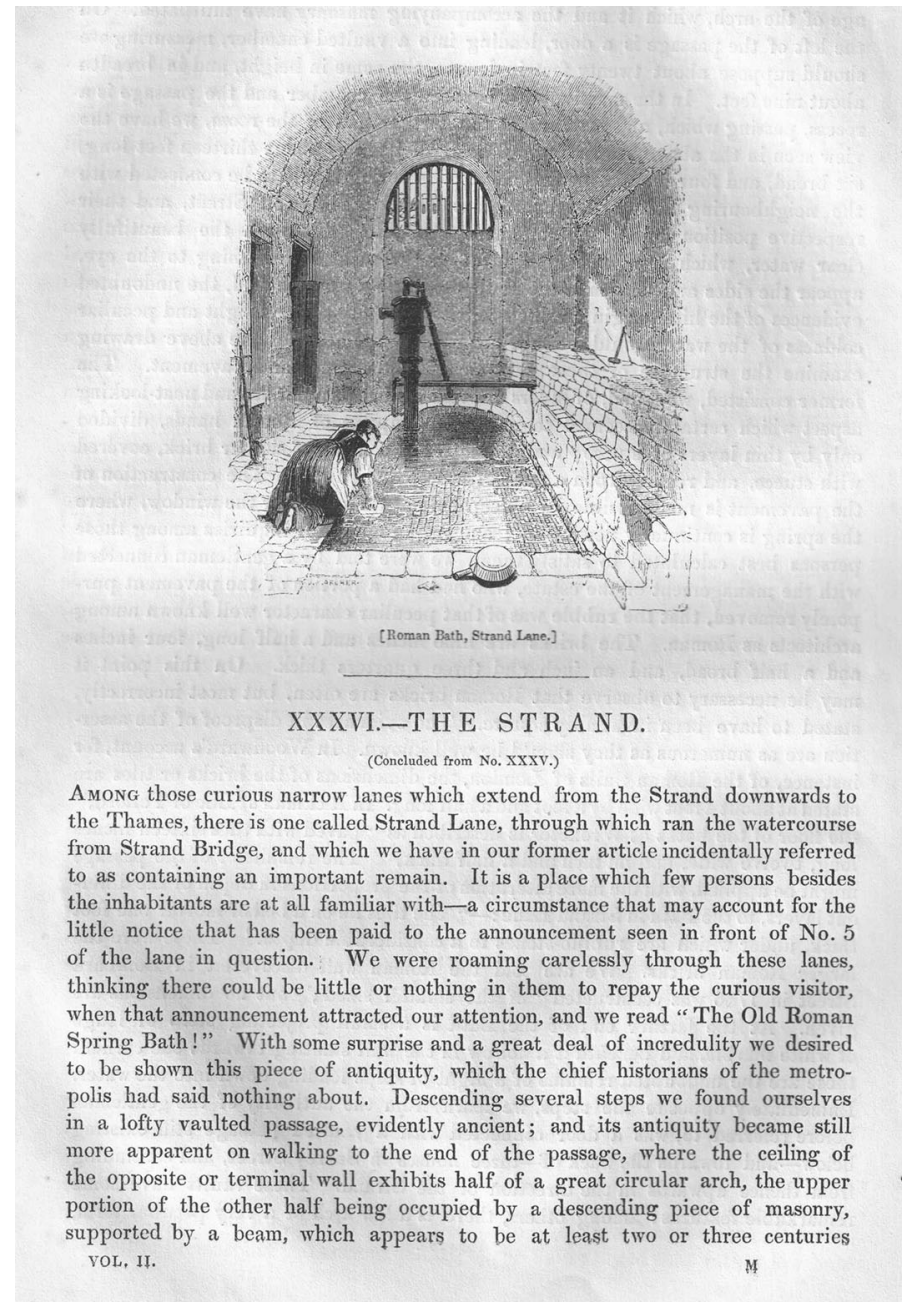

Fig. 5 C. Knight (ed.), London, II, 1842, p. 165 (photo: author)

be shown this piece of antiquity, which the chief historians of the metropolis had said nothing about.

Incredulity gives way to delighted belief - in what is to be another long-running reaction - when confronted with the evidence of their eyes: 'Descending several steps we found ourselves in a lofty vaulted passage, evidently ancient; and its antiquity became still more apparent on walking to the end of the passage, where the ceiling of the opposite or terminal wall exhibits half of a great circular arch ...'

Saunders proceeds to describe the appearance and fabric of the bath itself and its enclosing vault, continuing to emphasize the progressive overcoming of initial scepticism by a combination of further visual evidence, careful enquiry and 
informed reflection. As far as 'the height and peculiar coldness of the water would permit' he and the artist examine the fabric, and find it to be composed of 'layers of brick of that peculiar flat and neat-looking aspect which certainly seemed to imply the impress of Roman hands.' They are intrigued by the hole in the floor of the Bath through which the water enters, where the nature of the brickwork and its underlay is made visible. Pursuing their enquiries 'among those persons best calculated to satisfy them', they are told by 'a gentleman connected with the management of the estate' that rubble found supporting the brick floor of the Bath 'was of that peculiar character well known among architects as Roman.' Continuing the line of thought on his own account, Saunders observes that the rectangular shape of the bricks used $\left(9 \frac{1}{2} \times 4 \frac{1}{2} \times 13 / 4\right.$ in) is no bar to their being Roman, since the common assertion that Roman bricks are invariably square is false: copious evidence from reports of brickwork on other Roman sites proves the contrary, and the structure of brick on mortar on rubble is exactly what was found in the baths at Wroxeter. ${ }^{34}$ Vaulted passageways behind the Bath, including a curious kind of nodding round-headed arch (apparently reported to Saunders and Archer by their informant rather than actually seen by them), strengthen the general impression of antiquity ${ }^{35}$ It is true that no mention of the Bath is to be found in any of the accredited historians of London, but local tradition fills the gap and adds a convincing picture of dereliction and rediscovery: 'from time immemorial in the neighbourhood the fact of its being a Roman bath has been received with implicit credence; - and ... a kind of dim tradition seems to exist that it had been closed up for some long period, and then rediscovered.'

Having thus built his case, Saunders can conclude with a confident assertion of the truth of the claim to a Roman origin and of the special value of this extraordinary relic:

It will not be thought that we have spent too much of our attention on this matter when it is considered how great an interest has always been felt on the subject of any remaining traces of the residences of the former masters of the world in our own island, and particularly in London; and that among those remains, consisting chiefly of fragments of walls, mosaic pavements, and articles of use or ornament, a bath, presenting today, probably, the precisely same aspect that it presented sixteen or seventeen centuries ago, when the Romans descended into its beautiful waters, must hold no mean place. The proprietors, we are happy to say, rightly estimate its value, and have long ago caused another bath to be built and supplied from it; and it is in the latter alone that persons are allowed to bathe.

\footnotetext{
${ }^{34}$ Saunders's reference here is to the description of the discovery of the Wroxeter baths in 1788 reported in J. Rickman, Life of Thomas Telford, Civil Engineer, London, 1838, Appendix (A.), pp. 287-9. See also R. Turner, 'Thomas Telford the Archaeologist', Antiquaries Journal, 88, 2008, pp. 365-75.

35 These 'passageways' still exist between the Bath and Nos 33-4 Surrey Street, though their continuation behind No. 35 was demolished when that house was rebuilt later in the century. They are in fact the remains of the vaults attached to the mansion house built by Simon and Nevinson Fox at the end of the 17th century, and subsequently owned by Thomas Vernon and the Danvers family, which burned down in 1765 and was replaced by Nos 33-5.
} 
For the Roman credentials of the Strand Lane Bath, its appearance in Knight's London was clearly a defining moment. From this point onwards, it became possible to see the Bath not simply as a mundane commercial operation in a minor backstreet, suitable only for small ads in the newspapers, but as a fascinating and undeservedly neglected historical curiosity. Saunders's skilfully constructed account, highlighting the intrigued reflections that the Bath and the story of its origins provoke in the visitor as much as its physical appearance, reinforced by Archer's strong and simple image, and the prominent placing of the whole on the cover of a weekly instalment (subsequently the head of a chapter) of a widely circulated publication, propelled Charles Scott's publicist's copy into official respectability and placed the Bath itself squarely on the agenda for popular antiquarian writing about London and the history of Roman Britain.

The second intervention, which not only lent further credibility to Scott's invention, but added a new layer of interest on its own account, came from a still larger and more celebrated figure on the contemporary stage than Knight. April 1850 saw the publication of Part XII of Charles Dickens's The Personal History, Adventures, Experience, \& Observation of David Copperfield. In Chapters 35 and 36 of this narrative David recalls how, in the painful confusions of first love, he sought the help of some cold water:

There was an old Roman bath in those days at the bottom of one of the streets out of the Strand - it may be there still - in which I have had many a cold plunge. Dressing myself as quietly as I could, and leaving Peggotty to look after my aunt, I tumbled head foremost into it, and then went for a walk to Hampstead. I had a hope that this brisk treatment might freshen my wits a little; and I think it did them good ....

..... (Ch. 36) I began the next day with another dive into the Roman bath, and then started for Highgate. I was not dispirited now. .....

This too was to prove a hugely important name-check. In the first instance, it brought the supposed Roman-ness of the Bath to public attention once more, this time in the eagerly devoured work of an emerging modern master, and in tones that treated its Roman origins as simple matter of fact. In the longer term, as Dickens himself became a public monument, it embedded the Bath and the story of its past in his biography and in the literature devoted to documenting the topography of his life and works. For David Copperfield is by a long way Dickens's most autobiographical novel, and was soon recognized as such by readers and critics. ${ }^{36}$

That direct knowledge (and probably also use) of the Bath does indeed count among the autobiographical elements is easy enough to believe. The young Dickens (b. 1812) lived at various central London addresses from the early 1820 s onwards. In the early 1830s, as he began his career as political journalist and sketch-writer, his lodging places included Furnival's Inn on High Holborn, only a mile or so north

\footnotetext{
36 See for instance the careful discussion of the extent of the autobiographical component in J. Forster, The Life of Charles Dickens, II, London, 1874, pp. 128-9.
} 
of Strand Lane, and George Street and Cecil Street off the Strand itself. ${ }^{37}$ His first published collection, Sketches by Boz (1836) centres on London life and characters, and Ch. 7, 'The Steam Excursion', has the story's central character, Mr Percy Noakes, a law student of Gray's Inn, walking down from his chambers past Temple Bar and down Strand Lane to the river, in order to catch a boat to the steamer Endeavour. And Dickens himself, in a hasty note written in the spring of 1833, can be seen arranging for his friend and future brother-in-law Henry Austin to be met by a boat at the foot of the Lane. ${ }^{38}$ If he knew the Lane, it is natural to suppose he knew the Bath, and if he knew it he may well have used it.

Dickens's reference does however also raise a chronological problem. In Copperfield, he makes David refer casually and naturally to the Bath as Roman. Yet at the implied date of David's youthful plunges (1820s), as also at the date of Dickens's own documented familiarity with Strand Lane, it seems - if what I have proposed above about Charles Scott is correct - that the Bath had not yet had its Roman baptism. Perhaps the story of Roman origins had in fact come into circulation rather earlier than the later 1830s, in spite of the grounds given above for supposing otherwise. More probably (I hope) Dickens was projecting back into David's youth in the 1820s what he himself knew to be true in 1850; after all, if the Bath was known to be Roman in 1850 , it must already have been so in, say, 1825 . It is certainly the case that his reference to the Bath is imprecise in another respect. He has David 'tumbling head foremost' and 'diving' into it, but this is at odds with the dimensions of both the 'old Roman well' (which we know from Saunders to have been banned to bathers at some time before 1841) and its marble-lined partner ${ }^{39}$; to dive head-first into either would have been to risk serious injury. Vigorous phrasing (combined with a sense of what you ought to be able to do with a cold plunge bath) would seem to have taken precedence over pedantic factual accuracy.

Knight (Saunders) and Dickens between them thus canonized the Strand Lane Bath's claim to Roman antiquity, publicizing it to a wide middle-brow readership, stamping it with their authority, and in their different ways setting the terms of reference on which it would be repeated, embroidered and debated for the succeeding century. The Roman origins of the Bath, and its remarkable survival in its original function and even what looked like its original housing, became a fixture in antiquarian writing about the capital, in guidebooks and travel-writing, and in Dickensiana. It is to the details of how this perception was expressed over the years from the 1840s onwards that we may now turn. We shall find that, although by no means everybody who repeated it whole-heartedly endorsed it and even expressions of downright scepticism are not lacking from a fairly early stage, and although its strongest appeal was always to the imaginations of romantically inclined amateurs rather than to those who thought of themselves as hard-headed archaeologists or historians, this is a story that was to prove extraordinarily tenacious and resistant to conclusive disproof.

\footnotetext{
37 C. Tomalin, Charles Dickens: A Life, London, 2011, p. 40 (with n. 13 on 425).

38 J. Hartley (ed.), The Selected Letters of Charles Dickens, Oxford, 2012, p. 6.

39 The 'Roman Bath' measures $4.8 \mathrm{~m}$ long by $2.1 \mathrm{~m}$ broad by just $1.32 \mathrm{~m}$ deep, the adjacent 'Essex Bath' $3.9 \mathrm{~m}$ long by $2.5 \mathrm{~m}$ broad by $1.38 \mathrm{~m}$ deep.
} 


\section{From the 1840s to (Roughly) the 1890s: Uptake and Diffusion}

As just suggested, the uptake of the story of the Bath's Roman origins can be traced in a number of different kinds of publication: popular antiquarian writing about the history and curiosities of London, guide-books and travel literature dealing with London in general, and the more specialized literature devoted to the London of Charles Dickens. If we discount Knight's recycling of his own material - Archer's engraving of the Bath was reproduced as part of a full page of images of RomanoBritish remains in Old England, published in 1845, and an abbreviated version of the text appeared in the Cyclopedia of London in $1851^{40}$ - the popularizing antiquarian uptake apparently begins with mentions in two anonymous publications: London in the Olden Time; Or, Sketches of the Great Metropolis from its Origin to the XVIth Century, ${ }^{41}$ which appeared in 1851, and the article 'Ancient London - No. VIII' in the journal The Home Friend for 27 July 1853. The former strikes a cautious note, declaring the bath 'apparently Roman' and 'decidedly Roman in appearance', and also endorsing the local tradition that it had been a bath as 'very probable'. The latter is both much more substantial and much less reserved, treating the Roman pedigree of the bath as certain, and proceeding to trick out a description of it (clearly based on Saunders but enhanced by additional personal observations) with a long quotation from the Roman writer Seneca's famous letter on baths and bathing, ${ }^{42}$ and a reference to Vitruvius's advice on where to put the windows. ${ }^{43}$ This seam then continues with John Timbs's Curiosities of London and William Newton's London in the Olden Time, both of 1855, and Edward Walford's article on 'The old Roman Bath in the Strand' in the periodical Once a Week for 9 April 1865 , later to be reprinted in a revised version in Vol. 3 of Walford's and Thornbury's Old and New London of 1878. ${ }^{44} 1868$ saw the publication of John Timbs's Some Account of the Parish of St Clement Danes (Westminster), Past and Present, ${ }^{45}$ and the article 'Walks round London, by a wandering boy', in issue 75 of the periodical The Boys of England. ${ }^{46}$

A kind of summary and punctuation mark in this strand of writing about the bath is reached with Old and New London, which like Knight's London of thirty years

\footnotetext{
${ }^{40}$ C. Knight (ed.), Old England: A Pictorial Museum of Regal, Ecclesiastical, Municipal, Baronial, and Popular Antiquities, I, London, 1845, p. 44 - a page of eight engravings representing Roman antiquities from London (Fig. 6). The other seven figures show a map of the Roman city and selected sculptures, ceramics and mosaics; the Strand Lane bath is the only piece of architecture shown. C. Knight, Cyclopedia of London, London, 1851, pp. 775-6.

41 London in the Olden Time; Or, Sketches of the Great Metropolis from Its Origin to the XVIth Century, London, 1851, p. 26.

42 Seneca, Moral Epistles, 86 (the portion quoted in English translation being paras 1-8).

43 Vitruvius, On Architecture, VI.4.

44 J. Timbs, Curiosities of London, London, 1855, p. 651; W. Newton, London in the Olden Time, London, 1855, p. 103; Once a Week, XII, 9 April 1865, pp. 514-18; E. Walford (ed.), Old and New London, III, London, 1878, Ch. 12. Walford also reprinted his account of the bath in his Londiniana, I, London, 1879, pp. 239-58.

45 London, 1868, pp. 265-7.

46 The Boys of England - a journal of sport, sensation, fun and instruction 75 (24 April 1868), pp. 356-7.
} 

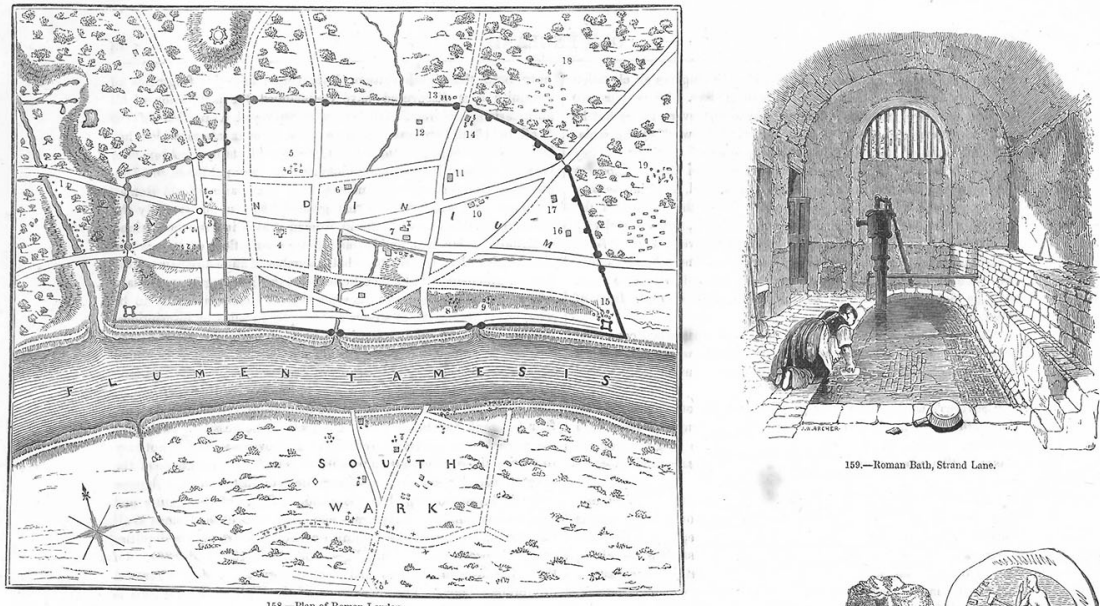

159.-Roman Bath, Strand Lane.
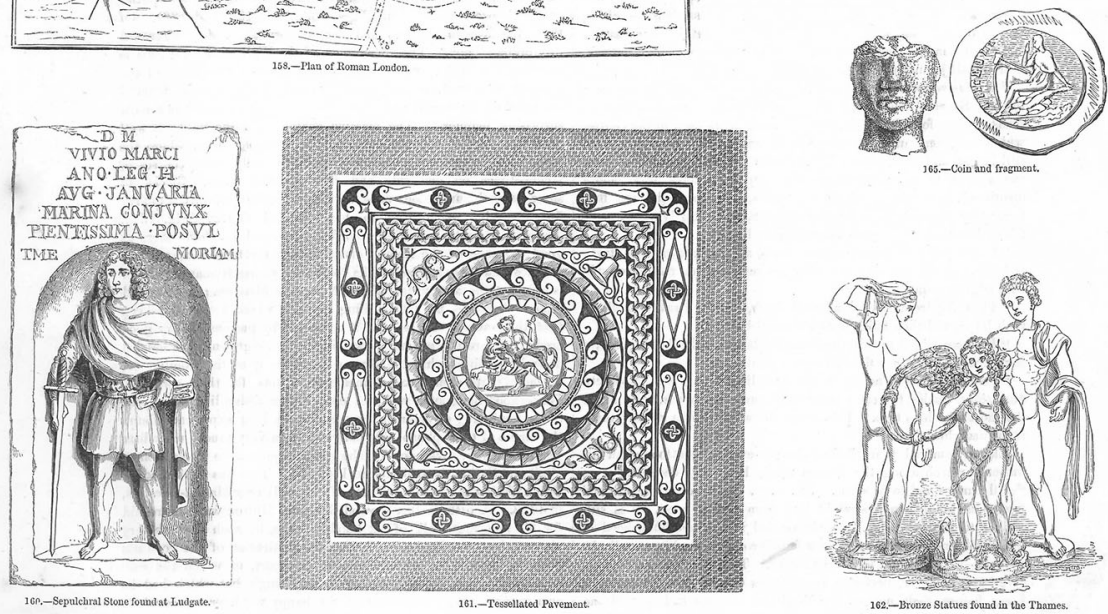

Fig. 6 Roman London, from C. Knight (ed.), Old England, 1845, p. 44 (photo: author)

before appeared in weekly instalments subsequently gathered into volumes. The first two consolidated volumes, edited by Walter Thornbury, were published in 1872 , with a six-volume expanded version, edited by Edward Walford, appearing in 1878. Thornbury briefly refers to the bath in the opening chapter of the whole work, and Walford's account, recycled from Once a Week, is included in Ch. 12 of Vol. III. ${ }^{47}$ In a way that is symptomatic of this whole antiquarian strand, Walford's description of the bath not only quotes John Saunders's extensively, but also follows it closely even when not quoting verbatim. Within the same span of years, the bath also features, once more as remarkably and undoubtedly Roman, in Augustus Hare's 'Walks in London': the walk in which the bath is included, following the Strand from Charing Cross to Temple Bar, appeared first in a number of the periodical

\footnotetext{
47 W. Thornbury (ed.), Old and New London, I-II, London, 1872; six-volume edition, Walford, Old and New London (n. 44 above). See Fig. 2.
} 
Good Words for February 1877, and then in Vol. I of Hare's collected Walks in London the following year. ${ }^{48}$

In all this, however, we may note one large and surely significant absence: the Bath finds no mention in Charles Roach Smith's wide-ranging and meticulous Illustrations of Roman London of $1859,{ }^{49}$ which held the field as the leading expert treatment of the archaeology of the capital for the remainder of the century, up until the appearance of the account in the Victoria History of London, published in 1909. ${ }^{50}$ Indeed, in a period in which systematic archaeology was only beginning to establish itself as a discipline and a body of technical writing, distinct from older aestheticizing and antiquarian approaches to the remains of the past, ${ }^{51}$ Roach Smith was one of the pioneers, beginning in earnest in 1848 with the first volume of his Collectanea Antiqua, based on work done in 1843. Further volumes continued to appear until 1880, running across what was in other terms the high point of his career, the purchase of his collection of mainly Roman antiquities in 1856 to be the nucleus of the British Museum's Romano-British holdings. The silence of this hardheaded and pugnaciously progressive student speaks volumes. Popular antiquarianism rather than the emerging specialist literature was clearly the Bath's natural habitat, just as the circle of authorities consulted by Saunders in his foundational work ('those persons best calculated to satisfy [our enquiries]', 'a gentleman connected with the management of the estate') seems not to have extended beyond enthusiastic lay informants.

Augustus Hare and the author of the article in Boys of England, on the other hand, show how well the Bath was adapted for inclusion in periegetic antiquarian writing, where the antiquities of the capital are described in topographic rather than chronological order - a move once more anticipated by Saunders, who not only arranges his materials topographically, but also explicitly introduces the Bath as a curiosity encountered as he and his companion 'were wandering carelessly through these lanes.' Topographic writing rubs shoulders with guidebook format, and the Bath established itself in the latter too at an early date. The earliest I have so far found is E. L. Blanchard's Adams's Pocket London Guide Book ... for the use of the Resident or Stranger, first published in 1851 and reprinted in revised form 1859 as Bradshaw's Guide through London and its Environs ... forming a complete and indispensable companion to the Resident and Stranger. ${ }^{52}$ Baedeker followed suit in

\footnotetext{
48 A. J. C. Hare, 'Walks in London, No. II', Good Words, February 1877, pp. 85-91, at 87; D. Macleod (ed.), Good Words for 1877, London, 1877, p. 87; A.. J. C. Hare, Walks in London, I, London, 1878, p. 37.

49 C. Roach Smith, Illustrations of Roman London, London, 1859. The subscribers were both private individuals and learned organizations in Britain, the Continent, and the USA, ranging from Charles Dickens and John Timbs to the South Kensington Museum, the British Museum Department of Antiquities, and the Cambridge University Library.

50 W. Page (ed.), The Victoria History of London, I, London, 1909, pp. 1-146 (by R. A. Smith, F. W. Reader and H. B. Walters).

51 On this process see again Hoselitz, Imagining Roman Britain (n. 16 above), Ch. 3 and P. Levine, The Amateur and the Professional, Cambridge, 1986.

52 E. L. Blanchard, Adams's Pocket London Guide Book, London, 1851, p. 100; Id., Bradshaw's Guide Through London, London, 1859, pp. 76-7. In J. Gilbert, Gilbert's Visitor's Guide to London, London, 1851, however, the Bath appears only in a list of public baths on p. 217 as '5, Strand Lane, cold baths.'
} 
1862 in German, French and English, with a subsequent revision (1873 or earlier) adding the corroborative but wholly false information that materials found on the site of the Bath could be seen on display in the British Museum. ${ }^{53}$ In the following decade, the Bath is firmly entrenched for an American readership in the guidebook published first pseudonymously in 1872-1874 as Ess's American Guide to London and its Suburbs, and subsequently under the name Lewis Jefferis, as The American ('s) Guide to London, in 1873-1874, and again as Marsh's American Guide to London in further annual revisions between 1875 and $1882 .{ }^{54}$

The David Copperfield connection, though not noted in the general guidebooks just listed, is naturally highlighted with the arrival of works devoted specifically to the London of Dickens. These begin with T. E. Pemberton's Dickens's London; or, London in the Works of Charles Dickens of 1876, and continue with Robert Allbut's London Rambles 'en zigzag' with Charles Dickens of 1888, reissued in 1894 under the title London and Country Rambles with Charles Dickens, and as Rambles in Dickens Land in 1899 and 1903. ${ }^{55}$ There is a mention too in the chapter on 'London Localities' in Percy Hetherington Fitzgerald's Bozland: Dickens' Places and People, gently correcting Dickens for supposing that his David bathed in the Roman reservoir rather than in the later, marble-lined bath attached to it. ${ }^{56}$ Mention of the Bath is not however inevitable in works of this kind; it does not feature for instance in William Hughes's A Week's Tramp in Dickens-Land of 1891. ${ }^{57}$

It is perhaps not hard to understand why the uptake of the story of Roman origins was as enthusiastic as these instances show it to have been. Dickens's endorsement, in the flesh as well as in his fiction, was surely an important factor, but more important still was probably the reflection that the Bath, if genuinely Roman, provided London with something it otherwise lacked, and indeed was not to be had anywhere in the British Isles, even where the Roman remains were otherwise richest and most imposing: a complete Roman structure, still standing above ground level and still easily identifiable in its original function. ${ }^{58}$ The company Archer's engraving keeps when reprinted from Knight's London in Knight's Old England is telling: although grouped with five other images to represent Roman London, it is

\footnotetext{
$\overline{53}$ K. Baedeker (ed.), London und seine Umgebung, Coblenz, 1862 , p. 110; for the addition about the British Museum, see e.g., Londres, ed. K. Baedeker, 2nd edn, Coblentz and Leipzig, 1873, p. 98.

54 J. Ess, Ess's American Guide to London, compiled by Jay Ess, London/New York, 1872, p. 58; L. Jefferis, The American Guide to London, London, 1874, pp. 63-4; Id., Marsh's American Guide to London, 8th edn, London, 1879, p. 58.

55 T. E. Pemberton, Dickens's London; or, London in the Works of Charles Dickens, London, 1876, pp. 139-40; R. Allbut, London Rambles 'en zigzag' with Charles Dickens, London, 1886, p. X; Id., London and Country Rambles with Charles Dickens, London, 1888, p. 10; Id., Rambles in Dickens Land, London, 1899, pp. 10-11 (repr. London, 1903).

56 P. H. Fitzgerald, Bozland: Dickens' Places and People, London, 1895, p. 174.

57 W. R. Hughes, A Week's Tramp in Dickens-Land, London, 1891.

58 The Roman remains of Bath, which might spring to mind as a counter-example, in fact provided no competition at this time. The famous head of Sulis Minerva had been discovered in 1727, and the Gorgon head along with other fragments in 1790, but really substantial remains of the temple were not uncovered until 1867-9, and the Roman Great Bath not until 1879-81. See Hoselitz, Imagining Roman Britain (n. 16 above), pp. 177-9 and M. Todd, 'The Rediscovery of Roman Britain', in A Companion to Roman Britain, ed. M. Todd, Oxford, 2004, pp. 453-54.
} 
the only one to show an architectural remain of any kind, the others consisting of a plan of the Roman city, the Leadenhall Street Bacchus mosaic, the tombstone of Vivius Marcianus and a collection of small-scale sculptures (Fig. 6). ${ }^{59}$ There were embarrassing contrasts to be drawn with what other northern European cities had to show for themselves - the Cluny baths in Paris, for example, or the Aula Palatina and Porta Nigra at Trier - and this will have seemed all the more urgent and potentially painful the more firmly London came to see itself as an imperial city in its own right, and the modern successor to ancient Rome. ${ }^{60}$

\section{Antiquarian Nostalgia, Neglect and the Knowledgeable Foreigner}

As the century nears its end, however, a nostalgic tone is increasingly heard in references to the Bath. The tide of new building and urban improvement that ran so strongly in the last quarter of the century was making more and more of an isolated pocket out of its immediate surroundings on Strand Lane, and this in turn began to prompt fears for its physical survival - fears that were indeed to prove all too well founded in 1893-1894, with the expansion of the Norfolk Hotel on Surrey Street and the demolition of the newer of the two baths. Writing in 1888, Walter Besant, in a chapter of his Fifty Years Ago entitled 'London in 1837', lamented the modern neglect of the Bath and its omission from a recent survey of the disappearing 'springs, plunges and bathing-pools' of London, and observed sadly that 'some day, no doubt, we shall hear that it has been sold and destroyed, like Sion College, and the spring built over'. ${ }^{61}$ Percy Fitzgerald, in his Picturesque London of 1890, prints two full-page drawings of the Bath chamber and its surroundings in Strand Lane, accompanied by a text which, like Besant's, deprecates modern neglect of so rare and threatened an antiquity, and concludes that 'it is highly desirable that the bath should be secured to the City without loss of time, and its destruction thereby saved'. ${ }^{62}$ But already in 1884 W. J. Loftie, in his History of London, includes the Bath in a list of 'Buildings in the Suburbs which existed before the Restoration' and describes it as 'an interesting monument, which should be under special protection'. 63

In this context, the Bath's physical location could be seen both as an additional part of its charm and as an extra problem. On the one hand, it was a deeply attractive thought that so venerable a relic of such a distant and numinous past should still survive so close to the hustle and bustle of the modern Strand. This thought is

\footnotetext{
59 See n. 40 above.

60 On this topic see most recently Q. J. Broughall, 'Stones of Empire: Allusions to Ancient Rome in the Physical Fabric of the Victorian and Edwardian World', New Voices in Classical Reception Studies, 9 , 2014, www2.open.ac.uk/ClassicalStudies/GreekPlays/newvoices/Issue9/broughall.pdf, with references to earlier bibliography; also, more generally, and without specific reference either to London or to architecture, N. Vance, The Victorians and Ancient Rome, Oxford, 1997, Ch. 10.

61 W. Besant, Fifty Years Ago, London, 1888, pp. 43-4.

62 P. H. Fitzgerald, Picturesque London, London, 1890, pp. 49-50; the illustrations are by Hume Nisbet (see Fig. 7).

63 W. J. Loftie, A History of London, 2nd edn, II, London, 1884, p. 433.
} 


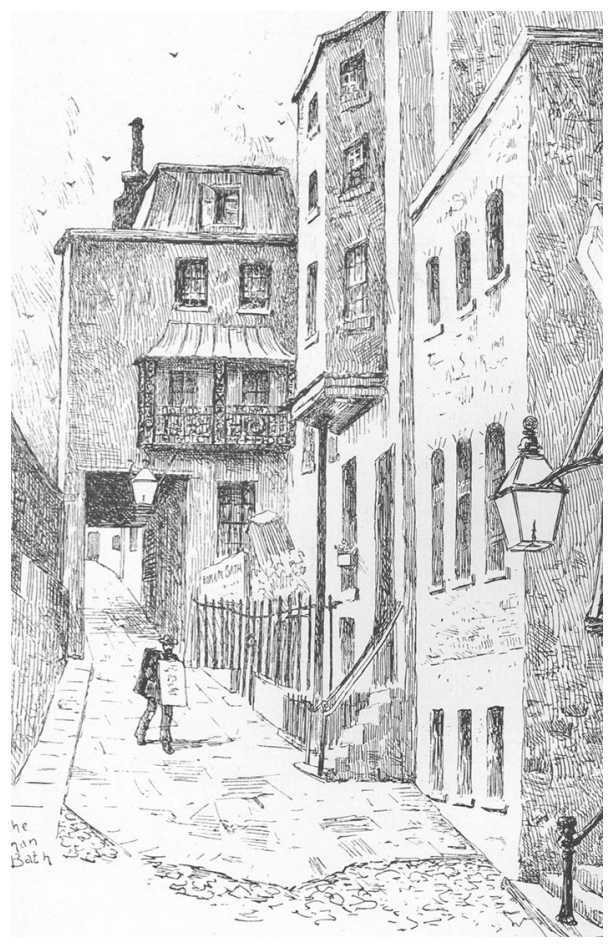

Fig. 7 Strand Lane, by Hume Nisbet (from Fitzgerald, Picturesque London, facing p. 49); the Roman Bath is to the right, behind the railings (photo: author)

played up most directly by Walford and Fitzgerald, Walford beginning the 1865 version of his account by wondering how many 'of the many hundreds and thousands of passengers, on foot or on horse, in cabs or omnibuses, who make the daily journey into the City viâ the Strand and Fleet Street ... fancy or imagine, as they pass the eastern end of Somerset House, that they are within some fifty or sixty feet of one of the oldest structures in London', while Fitzgerald asks whether even the most romantic of antiquaries would "think of looking for his "ancient Romans" or anything connected with them' 'in this exceedingly modern Strand', before divulging the 'astonishing surprise ... that we have only to turn out of the Strand hard by St Mary's Church' to 'see staring at us an invitation to come and look at a genuine, recognizable Roman work', but the same reflection echoes through many other accounts as well. Both Walford and Fitzgerald further accentuate it by underlining the 'olde worlde' aspect of the Bath's interior, as if caught in a wrinkle in time. Walford speaks of 'a somewhat rural cottage, on which hangs a card engraved with the words "The Old Roman Bath"'; Fitzgerald elaborates this to 'a sort of shanty of a house, such as we would see in a village, white-washed, a languid green creeper overgrowing it, which imparts quite a rural look.' This is the kind of place the serious enquirer could reasonably congratulate himself on having found, unlike the oblivious crowds on the Strand (Fig. 7). But at the same time, the 
obliviousness is also a concern if it is likely to lead to dangerous neglect and the risk of physical damage.

Over time, this perception of the Bath as unknown to the mass of Londoners also generates the thought (in either self-congratulatory or indignant versions) that it is in fact better known to outsiders: visitors from the provinces, or even more markedly visitors from abroad, and above all from America. As we have seen, guide-books aimed specifically at American tourists start to feature the Bath in the early eighteen seventies, and it is clear that their promptings were eagerly followed. The Civil War period emissary Thurlow Weed records a visit made in May $1862,{ }^{64}$ already reporting that 'I do not believe its existence is known to one thousand of the three millions of people who inhabit London.' In 1883, the journal American Architect and Architecture included it in a survey of baths and wash-houses in London and Paris, haughtily observing that 'the water is served out at two cents a pitcher to people whose passion for the ancient leads them to attach a sentimental value to this water' ${ }^{65} 1884$ saw a visit by the travelling Presbyterian clergyman W. P. Breed, reported in his Aboard and Abroad of $1885 .{ }^{66}$ All this prepares for the moment in 1885 when the travelling English clergyman the Rev. H. R. Haweis found himself ambushed by the superior knowledge of a group of young ladies at the Ogontz School in Pennsylvania:

My coup de grâce came when one of them inquired whether I had seen the Roman bath in the Strand. It was an awful temptation, but I felt I could not lie, and after a brief but, I am glad to say, a decisive struggle, I frankly admitted that I had not so much as heard that there was a Roman bath in the Strand! On re-entering, a guide book was, of course, produced, and a description of the fine specimen of Neronian brickwork still to be seen in the Strand, on what was formerly a portion of the Earl of Essex's house, was read out for my instruction. $^{67}$

This is a trend that was to continue, and even strengthen, in the succeeding decades. The wood-carver and restorer Harry Hems, lamenting the imminent destruction of the adjacent bath in 1894, recalls that during his visits to the establishment over the preceding twenty-five to thirty years 'I never remember having a fellow bather in

\footnotetext{
${ }^{64}$ T. Weed, Letter XXXVI of 12 May 1862, in Thurlow Weed's Letters from Europe, 1861-'62, 1862, pp. $143-6$ at 145 .

65 S. G. Young, 'Baths and Buanderies', American Architect and Architecture, 13, 1883, pp. 89-90 at 90. A buanderie (Fr.) is a wash-house or laundry; Young's concern was with the need for public provision of such facilities in American cities, on the model of Paris and Geneva.

66 W. P. Breed, Aboard and Abroad in Eighteen Hundred and Eighty-Four, New York and London, 1884, pp. 31-2.

67 H. R. Haweis, Travel and Talk 1885-93-95, London, 1896, p. 111. Haweis rapidly turned his discomfort to advantage, however, referring confidently to 'that fine Neronian brickwork, a good specimen of which may be seen in the Roman bath, Old Strand Lane, Strand' in his The Conquering Cross, London, 1887, p. 77. For the trope (Londoner abroad told about his own city by a foreigner) compare also H. V. Morton, 'The Heart of London. XXVIII - Our Roman Bath', The Daily Express, 10 January 1925, p. 7 (reprinted in H. V. Morton, The Heart of London, London, 1925, p. 198): 'An American once told me in Vienna that the Strand possesses a Roman bath well worth seeing, but, being a good Londoner, I did not believe him - till yesterday.'
} 
the shape of an Englishman, although many times Americans have shared the enjoyment of the plunge with me'. ${ }^{68}$ A London lady correspondent in 1907 reports how her own indignation finding the Bath closed on an August Saturday was easily surpassed by that of an American 'in a soft felt hat and pointed boots', who expressed his determination to search out the 'seketary' and demand admission. ${ }^{69} \mathrm{~A}$. H. Blake in 1919 records the presence of a street artist outside the Bath selling sketches of the interior at half a crown each 'to those, principally Americans, who come to visit'. ${ }^{70}$ H. V. Morton, writing in 1925, sees Chinese, Japanese, American, Canadian and Australian signatures in the visitor's book, but few from London, and is then told by the custodian that it is mainly the Americans and Canadians who want to undress and jump in 'not because it's a Roman bath, but because Dickens used to bathe here, and mentions it in ... "David Copperfield" , ${ }^{71}$ A high point of a kind in this line is reached in 1920, with the publication in Scribner's Magazine of a whimsical ghost-story by John T. Wheelwright (one of the founders of the Harvard Lampoon), in which a Dickens-obsessed young American visits the bath and bathes there with an anachronistically dressed young man who has mysteriously vanished before he emerges. $^{72}$

\section{Certainties and Doubts}

Through all of this writing, there is a degree of variation in the conviction with which the Bath's Roman credentials are endorsed. As we have seen, Saunders in his foundational contribution makes doubt and the overcoming of doubt a linking thread of his account, presenting the claim to Roman origins as something initially startling and unexpected, requiring to be tested and only gradually and cumulatively to be accepted as true. In this process, he gives special weight to the direct evidence of first-hand experience: the simple appearance of the brickwork of the plunge-pool and the shape and mass of its enclosing vault. Directly or indirectly, this seems to set a pattern for what follows. The continuing possibility of doubt is repeatedly acknowledged, explicitly or by implication, as writers either record the Roman identity of the Bath as supposition or tradition, or more frequently endorse it with a telling over-emphasis, as if admitting the existence of a lingering scepticism, in their own minds perhaps as much as in those of their readers. Some seek to bolster conviction by judiciously distinguishing between pool and the vault, using uncertainty about the age of the latter as means of underlining the greater credibility of the former; others happily assert the Roman antiquity of the whole

\footnotetext{
${ }^{68}$ H. Hems, 'An Elizabethan Bath - Must it Be Lost', The Antiquary, 30, 1894, p. 231.

69 N.S.R.G., 'Closed. London in August', Queanbeyan Age (NSW), 15 October 1907, p. 5 (reprinted from The Westminster Gazette).

70 A. H. Blake, Things Seen in London, London, 1919, p. 121.

71 Morton, 'The Heart of London' (n. 67 above).

72 J. T. Wheelwright, 'The Roman Bath', Scribner's Magazine, LXVII.1, 1920, pp. 33-41 (illustrations by Reginald Birch); reprinted in E. J. O'Brien (ed.), The Best Short Stories of 1920, Boston, 1921, pp. 312-19.
} 
structure, while wondering whether it did indeed begin life as a bath. The great majority not only continue to lay stress on the evidence of the eye - the brickwork and stonework simply look convincingly Roman - but it is also noteworthy how often a reference of this kind is rapidly followed by mention of the quality of the water, as if its manifest (and again, directly sensorily experienced) clarity and coldness were in some way proof not only of its derivation from a natural spring but also of the antiquity of the basin it was collected in.

Thus, the reference in Knight's Old England (again, presumably not penned by Knight himself) speaks only of a 'supposed Roman bath', but the accompanying page of illustrations sets it alongside real Roman sculptures and mosaics without qualifying comment. The anonymous London in the Olden Time of 1851, as already noted, speaks not only of it as 'apparently Roman', but also of the fabric as 'decidedly Roman in appearance' and the tradition asserting origins as a bath-house as 'very probable'. E. L. Blanchard's Adams's Pocket London Guide Book of 1851 calls it 'a genuine work of the Romans' and 'a remarkable piece of antiquity', but then speaks with a hint of reservation of 'vaults of Roman structure, indicating considerable [my italics] antiquity.' John Timbs in 1855 likewise speaks of 'accredited antiquity', but then adds that 'the bath itself [sc. as distinct from the vault] is Roman.' For William Newton in the same year, the whole ensemble is 'without doubt a veritable Roman structure, as inspection of the old walls will prove.' Edward Walford, writing in Once A Week in 1865 (the article subsequently reprinted in a revised version in Old and New London) characterizes it as 'one of the oldest structures in London' and 'one of the real and genuine remains ... from the era of the Romans in England', but hesitates over function: 'If indeed the place be in reality a Roman bath, of which no antiquary entertains a doubt.' The author of the article in The Boys of England (1868) speaks of it as 'Roman in its character' and 'built of materials evidently Roman, so we may conclude that some of the captains or centurions of the Roman legions were in the habit of laving their limbs in this very pool.' Ess's Guide of 1872 refers to 'unmistakable Roman bricks'. For Augustus Hare in 1877, it is 'one of the most remarkable relics of Roman London', 'enclosed in brick-work and masonry, apparently [? = 'manifestly'] Roman' and contains 'wonderfully cold, clear water ... from the miraculous well of St Clement.' W. P. Breed, writing in 1884, tells his correspondents of 'a remarkable and genuine relic of the London of the Romans ... a Roman bath-tub twelve feet long, surely long enough for the longest of the Romans ... and sparkling with crystal water from an overflowing spring, ${ }^{73}$

As the century wears on, the possibility of doubt, and perceptions of the possibility of doubt, seem to grow stronger. It is surely telling that the most obtrusively emphatic assertion of the genuine Roman-ness of the bath was that penned by Percy Fitzgerald in 1890, in his Picturesque London. In this account, prefaced by that reflection on how astonishing it is to find 'a genuine, recognizable Roman work, in sound condition' just a few paces down from the modern bustle of the Strand, Saunders's drama of surprise giving way to delighted conviction is played through one more time, but in notably heightened colours: "As we grow

\footnotetext{
73 Breed, Aboard and Abroad (n. 66 above).
} 
accustomed to the dim light, there is a sense of astonishment on looking round and finding ourselves before a genuine, unmistakable bath ... we can recognize the true fashion of Roman workmanship - the thin tiles of cheerful red, hard as iron, and the imperishable cement which has stood and resisted the water for centuries. The stately Roman look of the whole ... is extraordinary .... It is remarkable that this interesting relic, rare in any capital, should be so little known and so little esteemed.' It is as if Fitzgerald is consciously raising his voice to insist that those who, like Charles Roach Smith, simply omit the bath from their accounts of Roman London, are wrong, and to drown out the scepticism and amusement of the doubters.

For doubters there were, even if only intermittently visible. Prominent among them was the author of the humorous series 'The wayward wanderings of an educated nose', published in the journal The Judy between September 1882 and February 1883. In number ten (X) of this series, which appeared on 17 January 1883, the author takes a friend on a winding course from Short's Wine Bar on the Strand, via Somerset House, the Embankment, Surrey Street and the top end of Strand Lane, to the Roman Bath. In a knowing parody of the standard rhetoric, this is declared to be

one of the most remarkable and least known to sightseers of London sights, and of considerably more thrilling interest than London Stone. The antiquity of this bath is undoubted, the more so as no ancient historians - notorious liars to a man - make any mention of it. In Julius Caesar's time it was used for washing purposes, and here he probably composed the greater part of the wellknown Commentaries.

Such direct and calculated cheek is however rare, and perhaps not surprisingly. And what is nowhere to be found is any direct, argued rebuttal by any author constituting himself as a qualified authority on Roman or other antiquity. A large obstacle to any such intervention was pretty clearly the unavailability of any alternative story of the Bath's real origins (a problem that was to persist well into the twentieth century and even, in a sense, into the twenty-first). The emerging experts in Roman London might damn the bath implicitly by a lofty silence, but they had no way of saying what it actually was, and their dismissal therefore lacked the kind of impact that might seriously have shaken the widespread and for the most part affectionately embraced mythology.

\section{From Julius Caesar to Nero, Vespasian, Titus and Hadrian}

It was of course acknowledged from early on that the location of the Bath - now reckoned a substantial argument against a Roman date - posed a potential problem. Strand Lane is well to the west of the line of the city wall of Roman Londinium, which cut across the modern Ludgate Hill just east of Ludgate Circus and Old Bailey. But there was felt to be a plausible enough solution to hand. If the Bath was not within the Roman city, and indeed a kilometre or so outside it, then it must instead have been attached to a well-appointed suburban or even rustic villa. This comforting hypothesis seems first to be floated in the anonymous London in the 
Olden Time (1851), which conjures up the image of 'a handsome villa, on the banks of the Thames, whither some colonist had transferred the comfort and luxuries of that civilization, which had found its seat and flourished with such pride on the banks of the Tiber.' The thought is picked up and elaborated in a more romantic vein by the author of the 1853 article in The Home Friend, who pictures 'the villa of some Roman, smitten with the love of retirement, and the enjoyment of unsophisticated scenery.' This hypothetical Roman, the author continues, would surely have been equally well provided for whether his tastes ran to angling, lamprey-breeding, hunting or fowling, or indeed bird-watching: 'if [he was] a disciple of Pliny, the habits of the various small creatures which seek their food at the edge of a river - the flittings of the water-ouzel and the note of the sedge-warbler - would serve to amuse his contemplative mood.' There was room also for inflections inspired by more salacious, if equally stereotypical expectations of the ancient world. Arthur Beavan, in his Imperial London of 1901, envisages the villa of 'some wealthy merchant or leading official' where 'many a Julia or Poppaea may have laved her shapely limbs in this rough stuccoed cistern, thinking regretfully of the luxuries of the Empire's capital'. ${ }^{74}$ Others inevitably thought not of merchants or officials and their ladies but of legionaries and their centurions: so the author of the article in The Boys of England, noted above, but already before him G. R. Emerson in his London: How the great city grew of $1862,{ }^{75}$ and after him Richard Whiteing in his essay 'Heart Failures', contemplating the place where 'Legionaries had taken their morning plunge in the ice-cold spring'. ${ }^{76}$

There is variation too over the date envisaged. The most frequent assumption is that the bath belongs to 'the reign of Titus or Vespasian' (always named thus in reverse chronological order). This seems to surface first in Walford's 1865 essay in Once a Week as a tentative suggestion of the earliest likely date - 'from the era of the Romans in England, and possibly even as far back as the reign of Titus or Vespasian' - and is regularly repeated over the next half century and more, both in print and on the painted marble notice, probably of circa 1893, still visible in the Bath today. ${ }^{77}$ Although it is never explicitly articulated, the logic of this dating is presumably that it assigns the Bath to the period of the repacification and final expansion of the Roman province of Britain following the end of the Boudican revolt and the ructions caused by the Year of the Four Emperors (AD 69) - the period of the campaigning Governors Cerealis, Frontinus and Agricola. On this line of thought, any earlier dating would place the construction of the Bath in

\footnotetext{
74 A. H. Beavan, Imperial London, London, 1901, pp. 5-7.

75 G. R. Emerson, London: How the Great City Grew, London, 1862, p. 13: '19th century Londoners may yet descend the marble steps in Strand Lane and bathe as the legionaries bathed 1500 years ago.'

76 R. Whiteing, Little People, London, 1908, p. 87.

77 Walford's article repeated in Old and New London, and Londoniana; A. E. Wroth, 'A Roman Bath in London Two Thousand Years Old', The English Illustrated Magazine, 17, 1897, pp. 729-30 (an article widely reprinted, for example in The Church Standard, The Portsmouth Herald (New Hampshire), The Wilmington Morning Star (North Carolina) and The San Francisco Chronicle; 'Bathing with Caesar's Ghost', The Daily Express, 27 June 1901, p. 6; 'A Roman Bath in London', The Bystander, 22 August 1906, p. 388; the marble tablet in the Bath (visible, e.g., in one of the illustrations accompanying the article in The Bystander).
} 
implausibly troubled times: for instance, if it had been built before 60-1, it would surely have been destroyed by Boudica and her forces. Yet even Walford could not resist thinking wistfully of a still greater name in the history of Roman Britain, and adding 'if not of Julius Caesar himself', and others, with more enthusiasm and less historical scruple, followed suit. ${ }^{78}$ But equally, the Reverend H. R. Haweis can speak several times of the 'Neronian brickwork' of the Bath, on one occasion with the clear implication that the label was to be found in a current, probably American, guide-book. ${ }^{79}$ Hadrianic and fourth-century dates are also proposed. ${ }^{80}$ Charles and Marie Hemstreet assert with happy imprecision that the Bath 'has been here for fifteen hundred years' and that 'it is well worth passing through the door of No. 5 Strand Lane to look upon this relic and be assured that the days of Boadicea were real'. ${ }^{81} \mathrm{H}$. Barton Baker speculates that the Bath was used by 'men who gazed upon the face of Augustus or Nero, or may have talked with Pontius Pilate about the crucifixion of "the King of the Jews", 82

\section{Elizabeth and Essex Join the Party}

Irrespective of precise chronology, substantial support for belief in the Roman antiquity of the Bath came from what might be called its secondary or auxiliary myth: the idea that the other bathing-tank, the marble-lined plunge pool immediately to the south of the 'Roman' item, in fact built in or around $1778,{ }^{83}$ owed its origins to Queen Elizabeth's favourite the Earl of Essex. ${ }^{84}$ Although never topographically very plausible - Essex House in fact stood some distance away,

\footnotetext{
78 'Our Artist's Bird's-Eye View of the Week', The Penny Illustrated Paper and Illustrated Times, 27 July 1878, p. 62; 'Bathing with Caesar's Ghost', The Daily Express 27 June 1901, p. 6 (title, but not article); cf. R. M. Allen, 'London's Roman Bath', in Modern Sanitation, VII.9, August 1910, pp. 351-3 ('Let into the north wall of the room is a marble slab bearing the following inscription: 'Frigidarium. This old Roman Bath is supposed to have been built in the time of the Roman Emperors Titus or Vespasian.' This would place the origin of the building at about AD 70, but doubtless there was a bath there even before that date [my italics].')

79 H. R. Haweis, The Conquering Cross, London, 1887, p. 77; Id., Travel and Talk (n. 67 above).

80 'Picturesque London', The Daily News, 16 October 1890, p. 5 ('from the time of Adrian at the very least'); 'Some London Streets', The Gentleman's Magazine, 271 (July-Dec. 1891), p. 307 ('built around AD 300'); cf. Breed, Aboard and Abroad (n. 66 above), p. 32 ('If Julius Caesar did not bathe in this tub, perhaps Constantine did').

81 C. Hemstreet and M. Hemstreet, Nooks and Corners of Old London, New York, 1910, p. 115.

82 H. Barton Baker, Stories of the Streets of London, London, 1899, p. 262. This Christianizing reference is utterly characteristic of 19th-century British reflection on the Roman world: see again Goldhill, Victorian Culture (n. 25 above).

83 See Trapp, 'Georgian History' (n. 2 above), pp. 152-9.

84 The very earliest attempt to find significant history between Roman times and the modern world connects the bath complex not with Elizabeth but with Anne ('the old Roman baths, subsequently patronized by Her Majesty Queen Anne'), but this initiative does not seem to be picked up by any subsequent writer. It perhaps arises from a conflation of the Strand Lane establishment with another cold bath in Endell Street (Old Belton Street), which had also received some antiquarian attention in the 1840s. See Anon., 'The Precinct', All The Year Round, 12 May 1860, p. 117; and (for the Old Belton Street bath), Trapp, 'Georgian History' (n. 2 above), pp. 159-61.
} 
with Arundel House between it and the site of the baths, from around 1575 to around 1675 - the connection understandably proved irresistible to many. The earliest mentions, by Dr Robert Dudgeon in 1870 and Augustus Hare in 1877, carefully acknowledge it as hearsay; ${ }^{85}$ Edward Walford in the 1878 rewrite of his article for Old and New London adds the date 1588, crediting the information to the Bath's proprietor (who at this stage was the boxwood preparer John Howell, who worked for the Illustrated London News as well as keeping the Bath). Later references divide between those that retain a 'said to' or a 'some assert' and those which simply report the association as fact.

Hovering behind the shade of Essex is of course that of his still greater inamorata. The thought that 'Queen Elizabeth bathed here' is too good to pass over, and breaks surface a number of times, though usually with an element of selfconscious wishful thinking. Percy Fitzgerald in 1890 reports that the second bath is a sort of buff-coloured marble, and is known to have been made, and perhaps used, by the Earl of Essex some three centuries ago', before continuing more sceptically that 'our cicerone goes so far as to affirm that Good Queen Bess was fond of taking an occasional 'dip' here, and rather illogically points to a sort of darkened window or passage in proof of his assertion'. ${ }^{86}$ The Bystander article of 1906 asserts that Essex and other nobles used the bath, and that 'it has even been stated that the intrepid virgin Queen once, at least, plunged her fair form in its icy waters; but this lacks corroboration.' More flippantly, the Daily News of 16 October 1890, reviewing Fitzgerald's book, proposes that the bath, 'built by my Lord Essex in the time of Queen Bess' was 'perhaps used by him to quench the ardours of his passion for that Princess.' Such colourful fantasies were both entertaining in themselves, and naturally served to reinforce the Roman claims of the 'Essex bath's' twin, for if the clearly newer bath was Tudor, the clearly older one must go considerably further back in time. ${ }^{87}$

\section{The Bath in 1892}

At the start of the 1890s, therefore, the Bath's historical credentials as a rare and precious survivor of both the Elizabethan and the Roman past, all the more to be cherished because of the rapid modernization taking place around it, clearly seemed

\footnotetext{
85 R. E. Dudgeon, 'The Swimming Baths of London', British Journal of Homeopathy, 28, 1870, pp. 31-2 (quaintly complaining that 'the size hardly admits of anything in the way of swimming except mere paddling about'); Hare, Walks in London (n. 48 above), p. 87.

${ }^{86}$ Fitzgerald, Picturesque London (n. 62 above), p. 50; the passage referred to may have been the vaults first noted by Saunders, apparently running up towards the Strand, and the cicerone's idea may have been that these provided a secret access route for the Queen to reach the Bath, and Essex, unobserved.

87 In a further curious twist, at least one writer - Richard Whiteing in 'Heart Failures' - associates the Bath (apparently the surviving one, not the 'Essex' bath) with the Knights Templar, 'home from the Holy Land'; this is presumably a (deliberate or unconscious) corruption of a more plausible connection with Templars in the sense of inhabitants of the Inner and Middle Temple, just to the east (as for example in S. Sunderland, 'Old London's Spas, Baths and Wells', Presidential Address, Balneological and Climatological Section, November 26, 1914, Proceedings of the Royal Society of Medicine, 8, 1915, pp. 1-46 at 13, and Id., Old London's Spas, Baths and Wells, London, 1915, p. 40).
} 
well established to many. They may have lacked sanction in the most austerely professional literature on London's past - an increasingly serious matter as a more obvious divide began to open between such professional writing as the Survey of London and the Victoria County History ${ }^{88}$ and a more amateur, journalistic antiquarianism - but they nevertheless had a secure and apparently confident place in the majority of contemporary guidebooks and tourist itineraries. Romantic antiquarians and travellers, and the growing constituency of preservationists, alarmed at the increasing threat to the traces of an older London, particularly the dowdier and less spectacular ones, had strong incentives to believe in the Bath's historic value, and Roman origins (with at least the possibility of a significant Elizabethan connection too) made a particularly powerful way of giving that conviction a precise focus. Amused observers of this romanticism, like The Judy's Educated Nose, may have taken equal pleasure in exposing it to gentle scepticism, but even sceptical repetition served to keep the Roman story in circulation. Harderheaded sceptics, for their part, may only have held their fire from a feeling that the target was one not worth shooting at, but this forbearance too allowed the idea to continue to spread and root itself in the softer soil of kinder imaginations.

A characteristic statement of what might be called the default view can be found in a paragraph of an article 'Some London Streets', published in the Gentleman's Magazine in the second half of $1891 .^{89}$ The anonymous author's words nicely catch how the Bath continued to be cherished not only for its Roman credentials in themselves, but also for their contribution to the rich layering of diverse historical associations that could be perceived as giving London (and English culture more generally) its distinctive identity.

If you go past the east end of Somerset house, the great public building which, says the record, 'distinguished the reign of George III., and cost half a million of money', and take the sharp turning to your right, down the paved pathway of Strand Lane, you will come to the oldest Roman bath known to exist in London.

This is an old Roman bath built about AD 300, and lost sight of entirely when the Romans left Britain. It was found by accident in the days of my Lord Essex of Queen Elizabeth fame, who built himself a beautiful white marble bath, close to it and still extant. The Roman bath is fed by a spring which still flows from Highgate Hills, and falls (as the attendant will tell you) at length into the Thames. A curious arched chamber this, formed of dark red tiles, with layers of cement and rubble, much as the baths of Caracalla are lined, and corresponding exactly with the remains of our old Roman walls. Here are no pipes to conduct the spring, which rises from the very bowels of the earth, clear and unpolluted as crystal, and icy cold in mid-summer! If you are curious

\footnotetext{
88 The Survey of London was founded in 1894, the Victoria County History in 1899. In Vol. I of the Page, Victoria History (n. 50 above), the section on 'Romano-British London', in discussing the 'isolated villas in the districts of the Strand and Holbourn' refers cursorily and dismissively to 'what is supposed to be a Roman bath' in Strand Lane (82); the Topographical Index (136) refers likewise to 'the supposed Roman bath' and directs the reader to Knight's London (ii.165) for further details.
}

89 Gentleman's Magazine, 271 (n.s. 47), July-December 1891, 300-309 at 307. 
to test the origins of the beautiful water you see before you, stir the layer of sediment in the bath, and you will see bubbles rise. David Copperfield, you remember, was a stern believer in the merits of this bath, in which he was wont to indulge in 'many a cold plunge'. Did he, I wonder, attend at a certain St Clement Danes, and sit in the very same pew (with his back to the pillar) where Samuel Johnson once sat? I am sure, as it lies so near to the neighbourhood of his own street, he must have done so, though his biographer has failed to enlighten us as to this particular!

From whatever combination of deliberate purpose, incidental interest and casual tolerance, the story set in motion by Charles Scott in the later 1830s and consolidated by John Saunders and Charles Knight in 1841 had succeeded in capturing imaginations and perpetuating itself for a good half century and more. Looking back over that period from the vantage-point of 1892 or thereabouts, it is striking how very effectively Saunders in particular turned out to have done his work. His narrative of casual wandering in neglected byways enlivened by antiquarian discovery, of confident but initially implausible local tradition unexpectedly backed up by convincingly tangible and visible evidence, and of tantalizing remnants of mysteries still waiting to be explained, set up the story of the Bath's Roman origins as a piece of discovery and of direct personal experience rather than just a dry historical claim, and it is this emphasis that resonates through that story's reception over the next five decades.

The opening years of the Nineties, however, also bring us to the eve of farreaching change: change in the first instance to the physical layout and décor of the Bath, but in consequence of that also to its hold on the imaginations of enthusiasts and sceptics alike, and to the frame of reference within which its claims to Roman antiquity were to be considered. The story of this change and of what flowed from it, from the early 1890s to the later 1940s, when the Bath finally achieved the status of an officially protected ancient monument, will demand another study to itself. This one can end with the Bath still Roman for the vast majority of its Victorian visitors, cherishing a direct contact with classical antiquity through hard red brick and cold water in a dimly lit underground chamber simultaneously a few paces and a million miles from the noise and traffic of the Strand.

Acknowledgments I am grateful to Dr Roger Bowdler of English Heritage and the Archives staff at King's College London for giving me access to research materials. Comments from Dan Orrells on an earlier draft have made a crucial contribution to the finished product.

Open Access This article is distributed under the terms of the Creative Commons Attribution 4.0 International License (http://creativecommons.org/licenses/by/4.0/), which permits unrestricted use, distribution, and reproduction in any medium, provided you give appropriate credit to the original author(s) and the source, provide a link to the Creative Commons license, and indicate if changes were made. 